\title{
The Histomorphological Study on Testicular Cells of Hypercholesterolemia Rats Treated by Polysaccharides of Sea Cucumber, Holothuria nobilis
}

\author{
Fitrah A. Ulhusna ${ }^{1}$, Tutik Wresdiyati ${ }^{1}$, and Adi Winarto $^{1 *}$ \\ ${ }^{1}$ Department of Anatomy, Physiology and Pharmacology, IPB University, 16680 Bogor, Indonesia
}

\begin{abstract}
Hypercholesterolemia is a condition characterized by the presence of high levels of plasma cholesterol. This study aims to determine the morphological change of testicular cells in hypercholesterolemia rats treated by polysaccharides of sea cucumber, Holothuria nobilis. This study used 15 Sprague Dawley rats which was divided into 4 groups: non-hypercholesterolemia group (K-), hypercholesterolemia group (K+), prevention group that were given $1 \%$ cholesterol and $400 \mathrm{mg} / \mathrm{kg}$ of body weight polysaccharides (ChP), and curative hypercholesterolemia group that treated by $400 \mathrm{mg} / \mathrm{kg}$ of body weight polysaccharides (PCh). The $\mathrm{ChP}$ and PCh groups were treated for 28 days. Testicular tissue was processed histologically, stained with hematoxylin-eosin and Cusson's trichrome staining, and observed using a light microscope. The results indicated that the treatment of sea cucumber polysaccharides could improve the healing process of interstitial cells (Leydig cell). However, the 28 days of hypercholesterolemia has not affected adversely on testicular spermatogenic cell development.
\end{abstract}

Keywords: hypercholesterolemia, Leydig cells, spermatogenic cells, polysaccharides, sea cucumbers.

\section{Introduction}

Hypercholesterolemia represents a high-risk factor for coronary heart disease as it may predispose to cardiac ischemia, myocardial infarction, and atherosclerosis. Hypercholesterolemia is a condition characterized by the high level of total cholesterol (TC), triglycerides (TG), low density lipoprotein cholesterol (LDL-C), and very low density lipoprotein cholesterol (VLDL-C) [1]. Hypercholesterolemia is related to male reproduction system dysfunction, including a decrease in the quality of produced semen that leads to infertility [2].

Lifestyle changes such as a high-cholesterol diet and low physical activity cause increases in the fatty substance and cholesterol level in blood. A high cholesterol diet can enhance radical oxygen production and lipid peroxidation in some tissues. Lipid peroxidation can damage the sperm cell membrane, structure protein, and DNA (Deoxy Nucleate Acid). It is one pathways mechanism of how cholesterol influences sperm fertility [3]. A high cholesterol diet causes the reproduction problems by increasing the cholesterol level in the testes, leading to gonad cell degeneration and hypothalamus-pituitary gland dysfunctions which are related to short penis structure and spermatogenesis interferences. A low highdensity lipoprotein level will lead to an increase in total cholesterol which causes erection dysfunction [4].

A recent study said that polysaccharides are biomacromolecules that playing a role in inhibiting lipid peroxidation [5]. It has been reported that sea cucumber
Apostichopus japonicas and Metriatyla scabra have an antihyperlipidemic effect [6-7]. Meanwhile, there was no reported about using sea polysaccharides cucumber $H$. nobilis as antihypercholesterolemic. This study aims to determine the morphological changes of testicular cells in hypercholesterolemia rats treated by polysaccharides (preventive and curative ) of sea cucumber H. nobilis.

\section{Materials and Methods}

\subsection{Preparation of Polysaccharides Sea Cucumber (H. nobilis)}

Sea cucumber (H. nobilis) obtained from Ujung Genteng Sukabumi, West Java, Indonesia. Preparation of polysaccharides of sea cucumber according to the [6].

\subsection{In-Vivo Test of Effect of Polysaccharides of Sea Cucumber H. Nobilis in Hypercholesterolemic Rats}

In this study, 15 male Sprague Dawley rats aged 2.5 months were used $(15 \pm 5 \mathrm{~g})$. Rats were obtained from the Drug and Food Inspection Agency (BPOM). This study was approved by the Animal Care and Use Committee (ACUC) Bogor Agricultural University, Indonesia (license: ACUC No. 91-2018 IPB). The rats were divided into 4 groups, consisted of non-hypercholesterolemic group (K-), hypercholesterolemic group (K+), hypercholesterolemic prevention group which were given

Corresponding author: katanablack704@gmail.com 
$1 \%$ cholesterol diet and polysaccharides of sea cucumber at the dose of $400 \mathrm{mg} / \mathrm{kg} \mathrm{BW}$ (PCh), and the hypercholesterolemia curative group which was given $1 \%$ cholesterol diet for 28 days, then followed by $400 \mathrm{mg} / \mathrm{Kg}$ BW polysaccharides of sea cucumber days (ChP). All groups were treated for 28 days. At the end of the treatment, rats were anesthetized using a combination of ketamine $(70 \mathrm{mg} / \mathrm{kg} \mathrm{BW})$ and xylazine $(10 \mathrm{mg} / \mathrm{kg} \mathrm{BW})$. Rats testicular was taken to analyze the interstitial cell (Leydig cell).

\subsection{Testicular Tissue Processing}

Testicular tissue processing was done according to [8]. The testicular was washed by $0.9 \%$ physiological $\mathrm{NaCl}$ and fixed in Bouin's solution for 24 hours, then changes into a $70 \%$ alcohol solution as a stopping point. Then, followed by dehydration process, clearing of the tissue using xylol solution and infiltrated with liquid paraffin. Then, the tissue block was cut using microtome. The cut tissue was 4 micron in thickness, attached to object glass and was stained hematoxylin-eosin and Cusson's trichrome [9].

\subsection{Data analysis}

Testicular tissues observed by light microscope and descriptively analyzed.

\section{Results and Discussion}

The result of qualitative analysis of the interstitial cell (Leydig cell) on the testicular tissue showed that the interstitial cell (Leydig cell) of $\mathrm{K}+$ was found some damages in interstitial area the healing damage was found in PCh and ChP group (Figure 1).

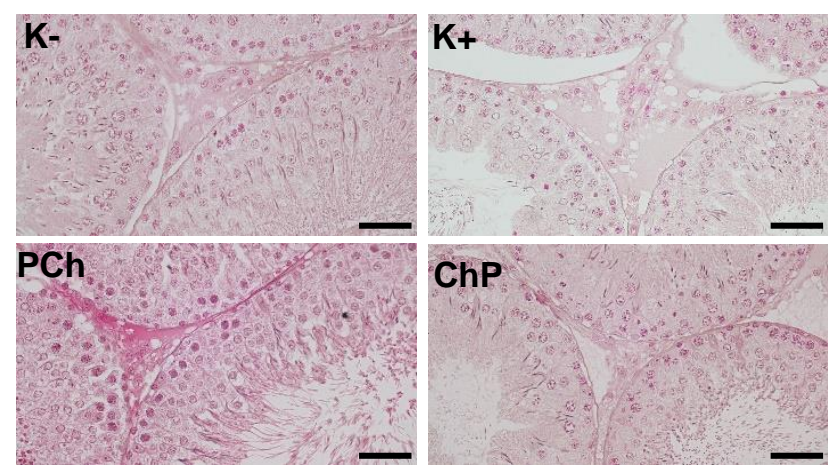

Figure 1, Histological image of testicular tissue with hematoxylin and eosin staining. (K-) non-hypercholesterolemic group, $(\mathrm{K}+)$ hypercho- lesterolemic group, $(\mathrm{PCh})$ hypercholesterolemic prevention group, $(\mathrm{ChP})$ hyper-cholesterolemia curative group. Scale bar: $50 \mu \mathrm{m}$.

In the K- group, the histological structure of Leydig cells was found has very clearly nucleus and found thighly organize. Different stages of spermatogenic cells could be identified clearly with small and round spermatogonia close to the basement membrane of seminiferous tubules and the primary spermatocyte, spermatid, and sperms distributed orderly toward the lumen. In $\mathrm{K}+$ group, the histological structure of Leydig cells was found in degeneration stage. Here also noted that edema image is found in the intersitial space. Evaluation on seminiferus tubules indicated that spermatogenic cells not afeected by this condition. Based on this condition could be understood that hypercholesterolemia for 28 days has no effect to the spermatogenesis activity. Cholesterol is a basic material for testosterone hormon. In the hypercholesterolemia, Leydig cells have a maximum limit in carrying out its functions. So that, the condition of hypercholesterolemia can cause Leydig cells degenerate. In the $\mathrm{Ch}$ dan $\mathrm{ChP}$ group, the histological structure of Leydig cells showed the healing proces of the Leydig cells. Thus the expansion of interterstial not occur.

Sea cucumbers have various types of polysaccharides, including fukoidan and fukosylate chondroitin sulfate. The sea cucumber $H$. nobilis contains fukosylate chondroitin sulfate [10]. Fukosylate chondroitin sulfate and fukoidan have been reported to be potentially antihyperlipemic [11] and reduce the risk of atherosclerosis triggered by hypercholesterolemia [12] by a number of mechanisms, including inhibit HMG-CoA reductase enzyme activity [13]; join with lipids and plays a role in cholesterol metabolism [14]; acts as a stimulator of bile acid synthesis and encourages lipoprotein lipase (LPL) activity by binding LDL oxidized by polysaccharides [15]. Polysaccharide $H$. nobilis is thought to be able to inhibit the activity of the enzyme HMG-CoA reductase, resulting in decreased cholesterol production. The low level of cholesterol in the body causes a low activity of bile synthesis followed by a decrease of free radicals accumulation so that the process of lipid peroxidation can be prevented. Thus, giving polysacharides in $\mathrm{PCh}$ and $\mathrm{ChP}$ group can inhibit the degeneration.

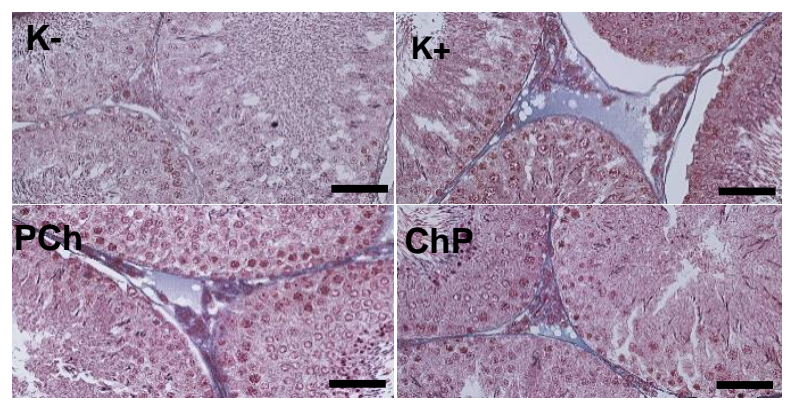

Figure 2. Histological image of testicular tissue with Casson trichrome staining. (K-) non- hypercholes-terolemic group, $(\mathrm{K}+)$ hypercholesterolemic group, $(\mathrm{PCh})$ hypercholesterolemic prevention group, (ChP) hypercholesterolemia curative group. Scale bar: $50 \mu \mathrm{m}$

Casson trichrome staining indicate that conective tissues fibre (thick blue line) was lightly found in control group (K-), but it more easy to found in hypercholesterolaemia a round the degenerate leydig at interstitial area. This may indicate a homoestasis in order to incounter the degenerated cells. In the prevention group (PCh) and currative (ChP) polysaccharides showed connective tissue that also filled several parts of 
degenerated Leydig cells. But the condition of $\mathrm{ChP}$ group better than PCh (Figure 2).

Giving polysaccharide is thought could improve the condition of leydig cells. This facts strongly indicate that suspected active compound in the polysaccharide $H$. nobilis could improve the healing condition in testicular cells.

\section{Conclusion}

Using the polysaccharide $H$. nobilis as ether preventive or curative to hypercholesterolemia rat could improve healing process on degeration interstitial cell (Leydig cell). However, the 28 days of hypercholesterolemia has not histological affect to the testicular spermatogenic cells.

\section{Acknowledgments}

The authors thanks the Indonesian Education Scholarship Program, the Education Fund Management Institution (LPDP) for funding this research.

\section{References}

1. Elahi MM, Kong YX, Matata BM : Oxidative stress as a mediator of cardiovascular disease. Oxid Med Cell. 2009; 2: 259-269.

2. Ashrafi $\mathrm{H}$, Ghabili K, Alihemmati A, et al. : The effect of quince leaf (Cydonia oblonga Miller) decoction on testes in hypercholesterolemic rabbits: a pilot study. Afr J Tradit Complement Altern Med. 2013; 10: 277-282

3. Ohara Y, Peterson TE, Harrison DG : Hypercholesterolemia increases endothelial superoxide anion production. J. Clin. 1993; 91: 25462551.

4. Bashandy AES : Effect of fixed oil of Nigella sativa on male fertility in normal and hyperipidemic rats. Int $J$ Pharm. 2007; 3:27-33

5. Shi L : Bioactivities: isolation and purification methods of polysaccharidesfrom natural products: a review. Int J Biol Macromol. 2016; 92: 37-48.
6. Liu XZ, Sun M, Zhang X, et al.: Antioxidant andantihyperlipidemic activities of polysaccharides from sea cucumber Apostichopus japonicas. Carbohydr Polym. 2012; 90:1664-1670.

7. Liu HH, Ko WC, Hu ML. : Hypolipidemic effect of glycosaminoglycansfrom the sea cucumber Metriatyla scabra in rats fed acholesterol-supplemented diet. $J$. Agric. Food Chem. 2002; 50: 3602-3606.

8. Eka P, I KMA, Tutik W : The Anti-Oxidant Activities of Ethanol Extract Of Mahogany (Sweitenia mahagoni Jacq.) Seeds In The Liver Tissues of Diabetic Experimental Rats. J Kedokt Hewan. 2017; 11:57-61.

9. Kiernan JA : Histological \& Histochemical Methods: Theory and Practice. 2nd ed. Pergamon Pr. Oxford. 1990.

10. Zou S, Rujia P, Xiaodi D, et al.: Physicochemical properties and antioxidant activities of two fucosylated chondroitin sulfate from sea cucumber Acaudina molpadioidea and Holothuria nobilis. Process Biochem. 2016; 16: 30021-3002

11. Li S, Zhia Z, Hu Y, et al.: 4-O-Sulfation in sea cucumber fucodians contribute to reversing dyslipidiaemia caused by HFD. Int J Biol Macromol. 2017; 99: 96-104

12. Xi C, Zhang R, Wen Z. : Bioactive compounds and biological functions of sea cucumbers as potential functional foods. J Funct Foods. 2018; 49: 73-84

13. Riessen R, Axel DI, Fenchel M, et al.: Effect of HMGCoA reductase inhibition on extracellular expression in human vascular smooth muscles cells. Basic Res Cardiol. 1999; 94: 322-332

14. Wang YM, Li ZN, Niu XZ, et al.: A preliminarystudy on antilipemic activity of polysaccharides from Ulva pertusa in mice. Chinese Journal of Marine Drugs. 2003; 22: 33-35.

15. Kaplan M, Aviram M: Macrophage plasma membrane chondroitin sulfate proteoglycan bind oxidized lowdensity lipoprotein. Atherosclerosis. 2000; 149: 5-17. 